\title{
THE DEVELOPMENT OF PHYSICAL CONDITION TRAINING TO IMPROVE PLAYERS PERFORMANCE IN TRADITIONAL SPORTS GALAH HADANG AT ADOLESCENT AGE
}

\author{
Nevi Hardika ${ }^{1}$ Rusdi $^{2}$, M Sabransyah $^{3}$, ,Asmutiar $^{4}$, Zainal Arifin ${ }^{5}$ \\ Pendidikan Jasmani Kesehatan dan Rekreasi, IKIP PGRI Pontianak ${ }^{1,2,3,4,5}$ \\ nevihardika@gmail.com ${ }^{1}$, rusdi@ikippgriptk.ac.id ${ }^{2}$, sabran.pjkr@gmail.com ${ }^{3}$, \\ asmu_tiar@yahoo.com ${ }^{4}$,Zai_inal@yahoo.co.id ${ }^{5}$
}

\begin{abstract}
This research aims to: 1) Develop a game-based basic motion learning skills model in upper-grade elementary school children. 2) Obtain empirical data about the effectiveness of the results of the development of learning models based on basic motion skills in primary school children. Method: using Research \& Development from Borg \& Gall with qualitative and quantitative approaches. The subjects of this study were 06 East Pontianak Elementary School and 34 South Pontianak Elementary School with 22 effectiveness test objects. Data collection techniques using descriptive qualitative (Expert Judgment). Analysis techniques data in this study used a qualitative percentage and a different test ( $t$-test) at $\alpha=0.05$. From the results of smallscale trial data recapitulation $(n=10)$ with the mean results obtained of 283 with a percentage of $78 \%$ categorized as Good. With the result 2 students are in very good category, 6 students are in good category and 2 students are in enough category. While the results of large-scale trial data recapitulation $(n=20)$, the mean result obtained is 600 with a percentage of $83 \%$ in the Good category. With the results of 12 students in very good category, 8 students in good category. While the effectiveness test ( $t$-test) can be proven by the pretest group and the posttest group showing the value of $t_{\text {count }}(12,122)>t_{\text {table }}(2.0797)$ with a significance of $0.000>0.05$. Meanwhile, the results of the posttest $t$-test results with the control group showed that the value of $t_{\text {count }}(10.350)>t_{\text {table }}$ (2.0797) with a significance of $0.000>0.05$. This shows that the data from the two groups have a significant variance, namely the value of $t_{\text {count }}>t_{\text {table. }}$. This shows that there is a significant difference so that it can be generalized and from the results of the difference between the pretest and posttest group means is 9.28 with an increase of $5.17 \%$. Meanwhile, the mean difference between the posttest group and the control group was 5.14 with an increase of $2.80 \%$. Therefore, it can be concluded that the development of a physical condition training model can improve the performance of players in traditional sports galah hadang in adolescence effectively and efficiently so that it can be applied to athletes.
\end{abstract}

Keywords: Development, Physical Condition Exercises, Traditional Sports Galah Hadang, Youth

Accepted: 29th of June 2021

Correspondenceauthor: Rusdi, IKIP PGRI Pontianak, Indonesia. E-Mail: rusdi@ikippgriptk.ac.id DOI http://dx.doi.org/10.31851/hon.v4i2.5298

\section{(i) (2)}

JurnalHalamanOlahraga Nusantara licensed under a Creative Commons Attribution-ShareAlike 4.0 International License. 


\section{OLATRAGA

\section{INTRODUCTION}

Sport is an activity that involves physical activity on an ongoing basis. So it must be developed through promoting sports and exercising the community, because sports activities have various goals and applications so that the position of sports becomes important in people's lives(Arisman, 2019). Sport makes people fitter and healthier which contributes to the ability of everyone to carry out their activities(Arisman \& Noviarini, 2021).

Traditional games are very much needed in creating future generations of Indonesia, especially nowadays where all children prefer to hold gadgets. Traditional games are a game inherited from the ancestors that must and need to be preserved because they contain local wisdom values (Mulyani\&Novi, 2016). traditional play will help character building children from an early age (Tuti Andriani, 2012), Traditional games can directly contribute to children in the form of: 1) physical formation that is healthy, fit, tough, superior and competitive; 2) mental formation includes: sportsmanship, tolerance, discipline and democracy; 3) Moral formation becomes more responsive, sensitive, honest and sincere; 4) the formation of social abilities, namely being able to compete, cooperate, be disciplined, friendly, and have a nationality(Hasanah, 2016), Traditional games are sports because all games use extra bodybuilding, traditional games are actually very good for physically and mentally training children. Indirectly, children will be stimulated by creativity, dexterity, leadership, intelligence, and the breadth of their insight through traditional games, in fact traditional toys are able to shape children's motor skills, both gross and fine(Yulita, 2017).

Game Galah Hadang is a game played by 5 insiders and 3 reserves in a team played on a flat field with a field size of $15 \times 9$ meters, consisting of 6 squares with a size of $4.5 \times 5$ meters each, (Disporapar Jatim, 2018). There are several strong reasons for elevating the nation's cultural dignity through traditional sports towards a healthy and fit physical condition. In the game of Galah Hadang, the physical condition is the most important in the implementation of this 
traditional game, therefore it takes extraordinary energy in its implementation and does not rule out the possibility of achievement(KPOTI, 2020).

Building a recreational sports coaching system is very important because this achievement can be achieved if the physical condition is strong and training is needed so that physical conditions can be formed and fostered which can be measured more clearly in accordance with the goals or goals set. Some of the strong reasons underlying the policy of lifting the dignity of the nation's culture through traditional sports towards being healthy and fit are(Peraturan Presiden RI, 2005):

First, in order to implement Law Number 3 of 2005 concerning the National Sports System and Government Regulation Number 16 of 2007 concerning the Implementation of Sports. These laws and government regulations clearly stipulate the duties and authorities of the government and local governments in sports development including fostering, developing and organizing national sports. Second, sports coaching is a multi-sector investment covering health investment, social investment, economic investment and cultural investment. Third, sport is becoming increasingly clear an instrument of government policy to strengthen the national identity. In this realm, the Government is determined to promote and revive the glory of Indonesian sports(Okilanda, 2017).

The purpose of this development is specifically for the promotion of cultural dignity and physical condition of players through traditional sports Galah Hadang can be active in organizing various activities to support the achievement of cultural preservation of traditional sports and can move to be active towards a smart, healthy, fit community, and Human.

\section{METHOD}

This research uses Research and Development from Borg \& Gall which consists of ten steps, including: (1) preliminary study, (2) collecting information (literature review and subject observation), (3) developing the initial product 


\section{DLATRAGA

design form (4) validation design, (5) design revision (according to the results in the field at the trial stage, (6)). Small-scale product trials, (7) product revisions (based on suggestions and main field trial results). (8) testing the use of large scale, (9) revising the final product, (10) mass production(Walter R. Borg \& Meredith D. Gall, 2013). The form and design used is to use mix methods research. Combining qualitative and quantitative(Sugiyono, 2015), this is intended to provide comprehensive data or information and explanation(Ali Maksum, 2012). The subjects of this study were students of the IKIP PGRI Pontianak with the effectiveness test of 22 students. The data collection techniques used include initial condition data, expert test result data and group trial data. This research is described as follows: Interview, Questionnaire / Questionnaire, Documentation (Barlian, 2016). Data analysis techniques: Data analysis techniques in developing this physical condition training model are to use qualitative and quantitative analysis techniques. Qualitative analysis techniques to analyze data from experts in the form of input, comments, criticism and suggestions. The results of data analysis form the basis for perfecting product development. The quantitative analysis technique or effectiveness test uses the t-test where this test is carried out to find out how much the results of the effectiveness are carried out by comparing the results of the pretest, posttest group with the control group with degrees of freedom (db) at the 5\% significance level(Nana Sudjana, 2010).

\section{RESULT AND DISCUSSION}

The results of the development of this physical condition training model, the researcher will explain the results of research in the form of overall data starting from preliminary research as the goal of developing a product, expert jusification and group testing, product testing and product effectiveness testing, and product discussion. 


\section{OLATRAGA \\ Jendral A. Yani Street Lorong Gotong Royong 9/10 U1u Palembang South Sumatera

1) Recapitulation of Test Value Results

Table 1. Recapitulation of Results

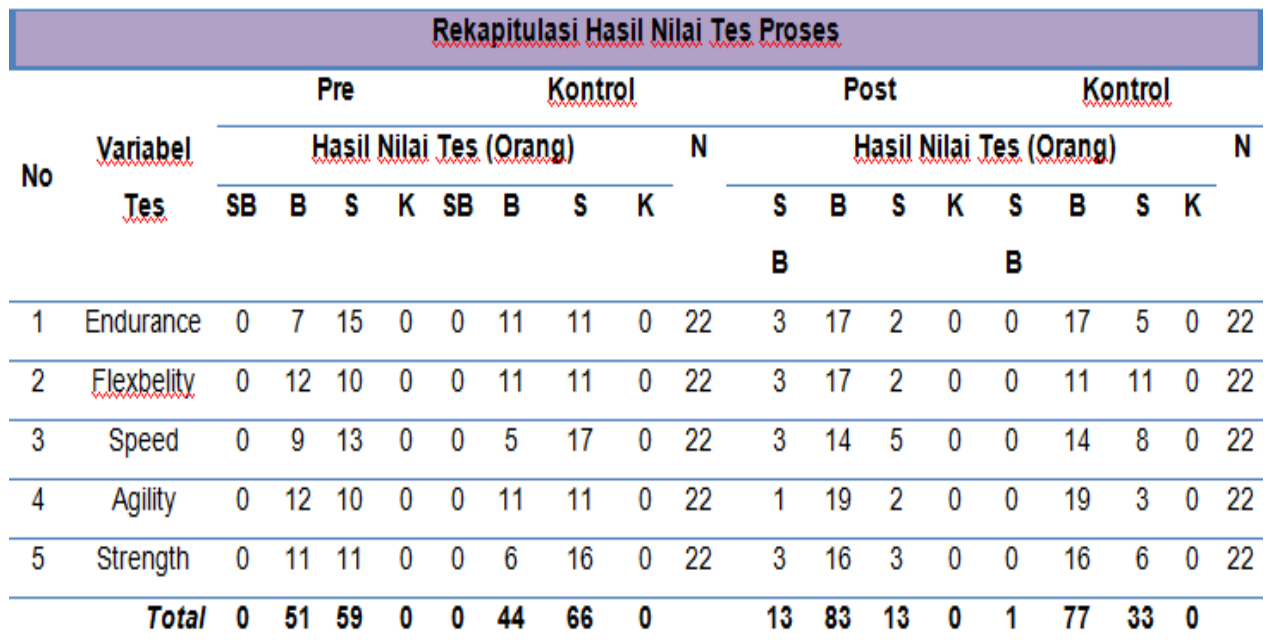

The table above shows that 22 respondents conducted 5 process tests, there was a significant increase as evidenced by the total results of 13 people who were categorized as very good or increasing, 32 people were categorized as good or increasing, 26 people were categorized as moderate or decreased.

Table2. Percentage of Average Yield Increase Per Test Item

\begin{tabular}{|c|c|c|c|c|c|c|}
\hline \multicolumn{7}{|c|}{ Percentage of Average Yield Increase Per Test Item } \\
\hline No & Variabel & (Mean \%) & (Mean \%) & $\begin{array}{c}\text { (Mean } \\
\% \text { ) }\end{array}$ & $\begin{array}{c}\text { (Mean } \\
\% \text { o) }\end{array}$ & $($ Mean \%) \\
\hline & & Endurance & Flexibility & Speed & Agility & Strength \\
\hline 1 & Pretest & 22.05 & 22.59 & 22.50 & 22.36 & 22.55 \\
\hline 2 & Control & 22.36 & 22.50 & 22.05 & 22.32 & 21.86 \\
\hline \multicolumn{2}{|c|}{ Improved } & .31 & .09 & .45 & .04 & .69 \\
\hline
\end{tabular}

The table above shows that the percentage of the results of the increase in the test is $0.31 \%$ endurance, $0.09 \%$ for flexibility, $0.45 \%$ for speed, $0.04 \%$ for agility and $0.69 \%$ for strength. 


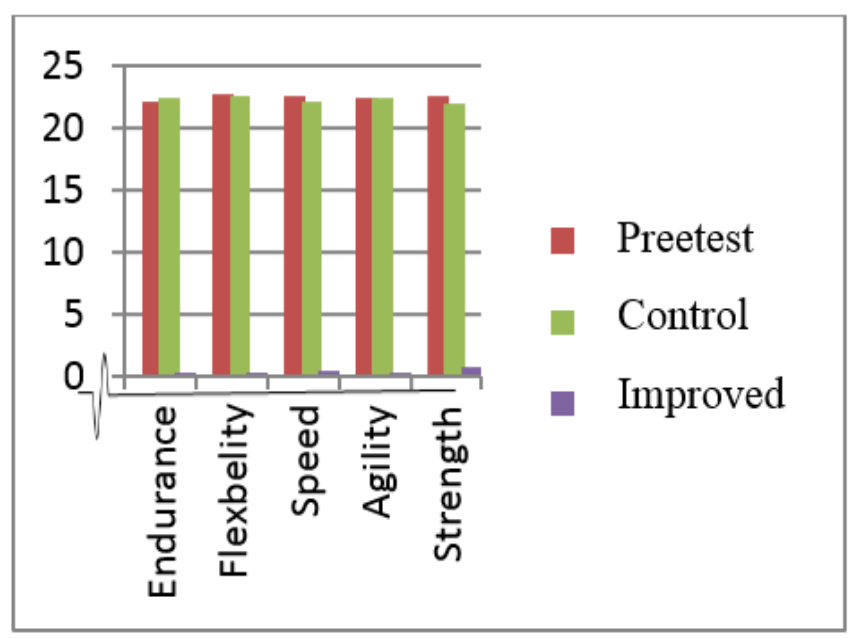

Figure 1. Presentation Graph Improved YieldAverage Value Per Test Item

Table 3. Presentation Graph Improved YieldAverage Value Per Test Item(treatment)

\begin{tabular}{|c|c|c|c|c|c|c|}
\hline \multicolumn{7}{|c|}{ Presentation Improved YieldAverage Value Per Test Item(treatment) } \\
\hline No & Variabel & (Mean \%) & (Mean \%) & $\begin{array}{c}\text { (Mean } \\
\% \text { ) }\end{array}$ & $\begin{array}{c}\text { (Mean } \\
\%)\end{array}$ & $\begin{array}{c}\text { (Mean } \\
\% \text { ) }\end{array}$ \\
\hline & & Endurance & Flexibility & Speed & Agility & Strength \\
\hline 1 & Posttest & 23.91 & 23.82 & 23.32 & 23.91 & 23.86 \\
\hline 2 & Control & 22.95 & 22.64 & 22.64 & 23.36 & 23.14 \\
\hline \multicolumn{2}{|c|}{ Improved } & .96 & 1.18 & .68 & .55 & .72 \\
\hline
\end{tabular}

The table above shows that the percentage of results of the increase in the test is $0.96 \%$ for endurance, $1.18 \%$ for flexibility, $0.68 \%$ for speed, $0.55 \%$ for agility and $0.72 \%$ for strength . 
HALAMAN OLAHRAGA JURAALJUIIKGOLIRAATARA email jurnal: jurnalhon@univpgri-palembang.ac.id

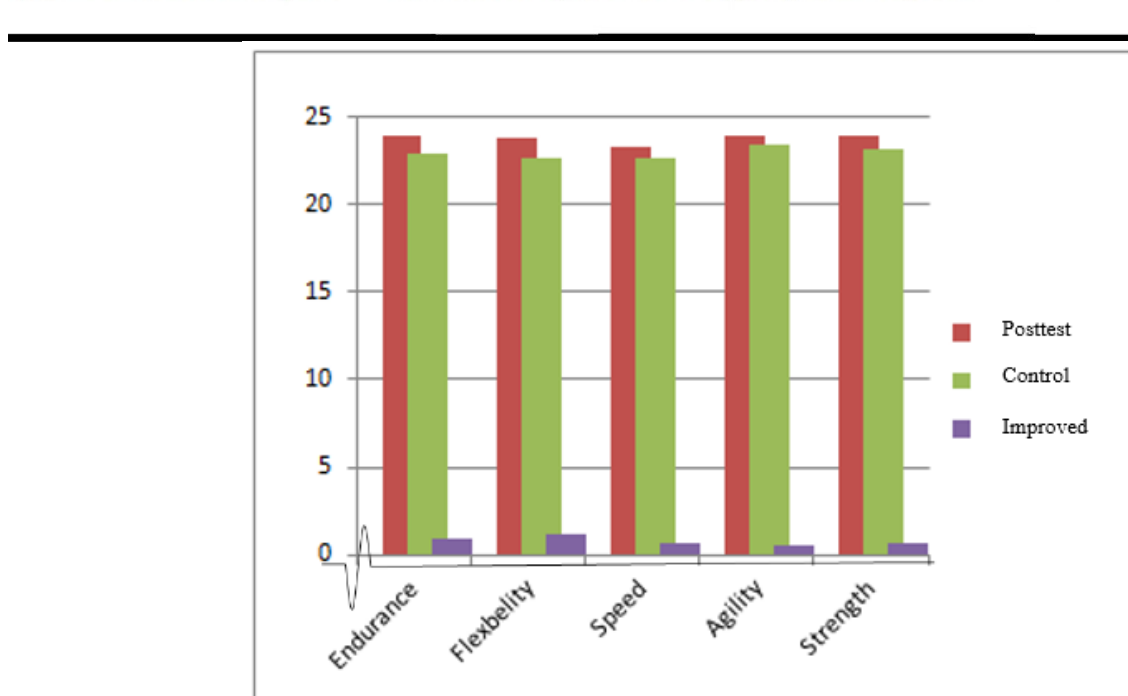

Figure 2. Percentage Graph Improved YieldAverage Value Per Test Item(treatment)

Table 4. Improved Test Result

\begin{tabular}{cccc}
\hline Group & Mean & Difference Mean & Enhancement \\
Pretest & 179.50 & & \\
Posttest & 188.77 & $\mathbf{9 . 2 8}$ & $\mathbf{5 . 1 7 \%}$ \\
Posttest & 188.77 & & \\
Control & 183.64 & $\mathbf{5 . 1 4}$ & $\mathbf{2 . 8 0 \%}$ \\
\hline
\end{tabular}

Based on the comparison of the results of the effectiveness test above, it can be concluded that there is a significant difference so that the new game model can be generalized as evidenced by the difference between the mean pretest and posttest groups obtained by 9.28 with an increase of $5.17 \%$. While the mean difference between the posttest group and the control group was 5.14 with an increase of $2.80 \%$.

\section{CONCLUSION}

Based on the research process that has been carried out and data analysis, the conclusions produced in this study are: 
1. Produce a physical condition training model that can improve the performance of traditional sports players.

In the effectiveness test, it can be interpreted that the physical condition training model in improving the ferform of traditional sports players developed by researchers can be applied and generalized to the gala hadang players and get a positive response from various groups as evidenced by the results of the posttest group test with the control group showing that the value of $T(10,349))>T$ table (2.0796) with a significance of $0.000>0.05$

\section{REFERENCES}

Ali Maksum. (2012). Metode Penelitian dalam Olahraga. UNESA University Press.

Arisman, A. (2019). Pengaruh Metode Rangkaian Bermain Terhadap Keterampilan Dasar Olahraga Panahan Siswa Ektrakulikuler Sit (Sekolah Islam Terpadu) Auladi Palembang. Halaman Olahraga Nusantara (Jurnal Ilmu Keolahragaan), 2(1), 1. https://doi.org/10.31851/hon.v2i1.2460

Arisman, A., \& Noviarini, T. (2021). Volume 4 No 1 Tahun 2021 ISSN 2614-2775 (Print) ISSN 2621-8143 ( Online) Tabata Workout Dalam Meningkatkan Kebugaran Universitas Mitra Karya, Indonesia . Abtrak Tabata Workout In Improving The Fitness of The 12 | Halaman Olahraga Nusantara Pendahuluan. 4(1), 12-22.

Barlian, E. (2016). Metodologi Penelitian Kualitatif \& Kuantitatif. Sukabina Press.

Disporapar Jatim. (2018). Kata Pengantar. In Juknis Invitasi Olahraga Tradisional (Vol. 1, Issue $1, \quad$ pp. 1-44). https://doi.org/10.24912/jmts.v2i3.7886

KPOTI. (2020). Buku panduan 5 olahraga tradisional 2019-1 (p. 44).

Mulyani, novi (2016)Super asyik permainan tradisional anak indonesia yogyakarta :DIVA Press.

Nana Sudjana. (2010). Dasar-Dasar Proses Belajar Mengajar.

Okilanda, A. (2017). Analisis Pembelajaran Gerak Keterampilan ....( Ardo Okilanda). 7, 31-41.

Peraturan Presiden RI. (2005). Undang-Undang Republik Indonesia Nomor 3 Tahun 2005 Tentang Sistem Keolahragaan Nasional (Issue 1, p. 57).

Sugiyono. (2015). Metode Penelitian \& Pengembangan Research and Development. Alfabeta. 
T Andriani.(2012).Permainan Tradisional Dalam Membentuk Karakter Anak Usia Dini jurnal sosial budaya.DOI: http://dx.doi.org/10.24014/sb.v9i1.376

Uawatun hasanah, (2016) jurnal pendidikan anak,vol 5 no 1 DOI: https://doi.org/10.21831/jpa.v5i1.12368

Walter R. Borg \& Meredith D. Gall. (2013). Educational Research An Introduction (4th Editio). Longman.

Yulita, R. (2017). Permainan tradisional anak Nusantara (Vol. 1). 